\title{
COMPARING EFFECTS OF SOIL AND FOLIAR APPLICATION OF POTASSIUM ON BALADY MANDARIN TREES
}

\author{
Ensherah A. H. Tayeh* and Khaled, A. Shaban** \\ *Hort. Instit; Agric. Res. Centre, Giza, Egypt \\ **Soil, Water and Environment Res. Instit; Agric. Res. Centre, Giza, Egypt
}

\section{ABSTRACT}

The experiment was conducted during three successive seasons from 2007 to 2009 on twenty five years old Balady mandarin trees budded on sour orange rootstock at $5 \times 5$ meter apart, planted in an orchard located at private orchard at El-Kalubia Governorate. The trees was in $(\mathrm{ON})$ year at the first season (2007), to investigate the effects of soil and foliar application of potassium on leaf (NPK), yield and some fruit physical properties (weight, volume, diameter, length, peel thickness, peel weight and some fruit chemical properties( T.S.S.\%, total acidity\%, T.S.S./ acid ratio, Reducing sugar, total sugar\% and Ascorbic acid. The experiment was divided into two parts, the first part was as soil addition and included four treatments $(0-200-400-800) \mathrm{gm}$ potassium sulphate $48 \% \mathrm{~K}_{2}$ Oper tree. The amount of potassium was divided into two equal batches the first dose added to the soil at mid March and the second added at August. The second part of the experiment was the foliar addition which included three treatments $(0-150$ and 300) ppm potassium sulphate, sprayed three times in mid March, May and July. All chosen trees received the usual dose of potassium which used in the orchard studied. Results revealed that all treatments led to increase leaf $\mathrm{N}$ and $\mathrm{K}$ contents. Increasing the rate of potassium was most effective to increasing leaf $\mathrm{N} \& \mathrm{~K}$, yield per tree and improved both fruit physical properties (fruit weight and volume, diameter length, peel weight and juice percent) and fruit chemical studied properties (T.S.S.\%, T.S.S./acid ratio, reducing sugar \%, total sugar\% and Ascorbic acid). While, leaf $\mathrm{P}$ was decreased. Concerning peel thickness, no trend was detected in the three seasons. So, the highest potassium rate had the highest values in all studied parameters except leaf $\mathrm{P}$ content, peel thickness and acidity. The main observation was about, $\mathrm{K}$ foliar application was most effective in increasing yield and improving fruit quality than soil addition.

\section{KEY WORDS: Potassium, Balady mandarin.}

\section{INTRODUCTION}

Citrus is one of the most important fruit crops all- over the world. In Egypt, citrus is the first crop and most of the total acreage are cultivated with different orange cvs. Potassium plays an important role in many of the plant metabolic processes namely, activation of enzymes, photosynthesis, transport of water and nutrients, translocation of sugars and starch. Potassium is very effective on the yield and fruit quality. Potassium is the most appropriate univalent cation for enzyme activation due to its mobility in the plant. Mengel \& Kirkby,(1978) and Almela et al;(1994). $K$ has important role in stomata movement and it is needed for enlargement of fruit. Faust,(1989) and Shishova and Lindberg (1999). $\mathrm{K}$ and $\mathrm{Ca}$ increased the yield, fruit weight, peel thickness and

Fayoum J. Agric. Res. \& Dev., Vol.25, No.2, July, 2011 
weight, T.S.S., total acidity and vitamin C. The amount of $\mathrm{K}$ application is very important for increasing the yield, leaf mineral contents, fruit weight, fruit juice percent. Peel thickness and weight were increased by increasing $\mathrm{K}$ doses. T.S.S.\% and total acidity $\%$ in the juice were increased by high $\mathrm{K}$ levels and caused a significant increase of juice Vit. C. Many investigators suggested that fertilization is one of the main factors affecting citrus production. A number of studies focused on fertilizer rates as well as fertilization methods in citrus orchards as those carried out, by who studied the effect of NPK as soil application and as foliar fertilization on yield and fruit quality of some citrus varieties. Similar studies were carried out by El-Kassas et al;(1987), , Khalil et al; (1987), Galal et al; (1987), Saleh, (1991), Hassan, (1993) and Maksoud et al; (1994). the increase in $\mathrm{N}$ and $\mathrm{K}$ leaf content with increasing the rates of applied $\mathrm{K}$ might be due to the positive effect in increasing roots as well as increasing their availability in the soil solution, subsequently more absorption through roots Smith,(1970). Darwish and Ahmed(1992) on Balady orange, Hassan, (1993) on Valencia orange, Zeerban et al;(1994) on Balady and Succarie orange varieties, Salama et $\boldsymbol{a l} ;(\mathbf{1 9 9 4})$ on Washington navel orange and Rabeh et al;(1993) on Balady mandarin

Accordingly, the present investigation aims to study the effect of different rates of $\mathrm{K}$ as soil and foliar application on yield, leaf mineral content and fruit quality of Balady mandarin.

\section{MATERIALS AND METHODS}

This study was performed from 2007to2009 seasons at a private orchard at ElKalubia Governorate. The study was achieved on ro- years old Balady mandarin trees budded on sour orange rootstock. The trees were spaced at $5 \times 5 \mathrm{~m}$ apart. All trees were chosen as uniform in vigor as possible and received the usual cultural practices, except those dealing with fertilization. The trees was in $(\mathrm{ON})$ year state at the first season (2007).

The investigation included sex treatments as follows:

\section{1- Control K(0) no potassium fertilization}

I-The soil addition:

Three rates of $\mathrm{K}$ applied as potassium sulphate $\left(48 \% \mathrm{~K}_{2} \mathrm{O}\right)$ i.e.

$1-\mathrm{K}(1), 200 \mathrm{gm}$ potassium sulphate $\left(48 \% \mathrm{~K}_{2} \mathrm{O}\right)$

$2-\mathrm{K}(2), 400 \mathrm{gm}$ potassium sulphate $\left(48 \% \mathrm{~K}_{2} \mathrm{O}\right)$

$3-\mathrm{K}(3), 800$ gm potassium sulphate $\left(48 \% \mathrm{~K}_{2} \mathrm{O}\right)$

The amount of potassium was divided into two equal doses and added the first dose at mid of March while, the second was added at August.

\section{II- Foliar spraying addition:}

1 - $\mathrm{K}(1), 150 \mathrm{ppm}$ potassium sulphate $\left(48 \% \mathrm{~K}_{2} \mathrm{O}\right)$

2- $\mathrm{K}(2), 300 \mathrm{ppm}$ potassium sulphate $\left(48 \% \mathrm{~K}_{2} \mathrm{O}\right)$

Triton $\mathrm{B}$ as a wetting agent at $0.1 \%$ was added to all spraying solutions. The trees were sprayed three times in the mid March, May and July, spraying was carried out till run off. The experiment was set in a completely randomized block design and included sex treatments replicated three times and each replicate represented by one tree, therefore, eighteen Balady mandarin trees devoted for this study. All chosen trees received the usual dose of potassium which used in the orchard studied.

Fayoum J. Agric. Res. \& Dev., Vol.25, No.2, July, 2011 
Studied parameters:

\section{1-Leaf mineral contents:}

Fifty mature leaves, seven- months old per tree were taken at random from the spring growth cycle fruiting shoots (first week of September) according to Summer(1985). The leaves were washed with a $0.01 \mathrm{~N} \mathrm{HCl}$ solution followed by rapid washing with distilled water. Then, samples were oven dried at $70^{\circ} \mathrm{C}$, ground and digested using $\mathrm{H}_{2} \mathrm{SO}_{4}$ as described by (Piper 1960). The digest was used to determine the following minerals according to corresponding procedures:

- Leaf(N) content was determined according to the method described by (Pregl,1945).

- Leaf (P) content was determined according to the method described by (Chapman and Pratt,1961).

- Leaf (K) content was determined according to the method described by (Brown and Lilleland, 1946).

\section{2-Yield and fruit quality:}

- Yield: At the time of commercial harvest ( $1^{\text {st }}$ week of December), total yield per tree for all treatments was weighed as kgs/ tree and recorded.

\section{3-Fruit physical properties:}

Ten fruits were taken at random from the yield of each tree. Fruit samples were tested for fruit weight (gms), fruit volume $\left(\mathrm{cm}^{3}\right)$, fruit length $(\mathrm{cms})$, fruit diameter $(\mathrm{cms})$, peel thickness (cms), peel weight(gms) and juice \%.

\section{4-Fruit chemical properties:}

Fruit chemical properties such as total soluble solids percentage, total acidity, T.S.S./ acid ratio was calculated. Reducing and total sugar percentages as well as vitamin $\mathrm{C}$ content (mgs vitamin $\mathrm{C} / 100 \mathrm{ml}$ of juice) were determined according to methods outlined in A.O.A.C.(1985).

statistically analysis:

All of the obtained data were statistically analyzed according to Snedecor and Cochran (1980) using Duncan Multiple Range test.

\section{RESULTS AND DISCUSSION}

Effect of $K$ rates as soil and foliar application on leaf (NPK ) contents:

Concerning leaf (NPK) contents, Table (1) declare significant increase in leaf content of $\mathrm{N}$ and $\mathrm{K}$ while, leaf $\mathrm{P}$ content was decreased, with increasing $\mathrm{K}$ fertilizer rate in the two addition methods ( soil or spraying), the increase of leaf $\mathrm{N}$ and $\mathrm{K}$ contents was significant in three seasons. The main observation was that spraying application was favorable than soil addition in increasing leaf (phosphorus and potassium) while, soil addition was better in increasing leaf nitrogen than spraying addition .Results concerning the increase in $\mathrm{N}$ and $\mathrm{K}$ leaf content with increasing the rates of applied $\mathrm{K}$ might be due to the positive effect in increasing roots as well as increasing their availability in the soil solution, subsequently more absorption through roots is occurred (Smith,1970). On the other hand, the observed reduction in leaf $\mathrm{P}$ content as a result of increasing $\mathrm{K}$ rates could be attributed to the antagonism occurring. (Darwish and Ahmed, 1992;Hassan, 1993 and Zeerban et al;,1994).

Fayoum J. Agric. Res. \& Dev., Vol.25, No.2, July, 2011 
Effect of $\mathrm{K}$ rates as soil and foliar application on yield:

Data presented in Table (1) show that, increasing the applied rates of $\mathrm{K}$ led to an increase the yield in kilograms comparing with the yield of control trees in the three seasons. The increment was significant in all seasons of the study. It is also clear that the treatment included the highest rate of $\mathrm{K}$ gave the highest yield per tree. However, in the "on crop" phase (2007 and 2009) the yield per tree was appreciably higher in 2009 season than that in 2007. It was evident that the yield of the trees were in the "on crop" phase was higher than in the "off crop" phase. On the other hand, the trees were sprayed by Potassium had higher yield than the soil addition specially in the case of spraying the high concentration of potassium. So, that spraying application was favorable than soil addition in increasing yield. These results are confirmed by the finding of Darwish and Ahmed (1992) on Balady orange, Hassan (1993) on Valencia orange, Salama et al; (1994) on Washington navel orange and Zeerban et al; (1994) on Balady and Succarie orange varieties.

Table (1). Effect of $K$ rates as soil and foliar application on leaf (NPK) contents and yieldof Balady mandarin trees.

\begin{tabular}{|c|c|c|c|c|c|c|c|c|c|c|c|c|}
\hline \multirow{2}{*}{$\begin{array}{l}\text { Character } \\
\text { Treatments }\end{array}$} & \multicolumn{3}{|c|}{$\mathbf{N}(\%)$} & \multicolumn{3}{|c|}{$\mathbf{P}(\%)$} & \multicolumn{3}{|c|}{$\mathrm{K}(\%)$} & \multicolumn{3}{|c|}{ Yield/tree (kgs) } \\
\hline & 2007 & 2008 & 2009 & 2007 & 2008 & 2009 & 2007 & 2008 & 2009 & 2007 & 2008 & 2009 \\
\hline K0(control) & 2.40 & 2.27 & 2.44 & 0.179 & 0.151 & 0.196 & 1.049 & 1.030 & 1.067 & 36.51 & 25.08 & 38.94 \\
\hline \multicolumn{13}{|c|}{ Soil addition } \\
\hline K1 (200gm K) & 2.48 & 2.43 & 2.52 & 0.175 & 0.159 & 0.190 & 1.078 & 1.063 & 1.093 & 44.08 & 26.99 & 48.16 \\
\hline K2(400gmK) & 2.56 & 2.51 & 2.61 & 0.163 & 0.158 & 0.167 & 1.098 & 1.093 & 1.103 & 46.04 & 28.83 & 50.34 \\
\hline K3(800gmK) & 2.61 & 2.55 & 2.67 & 0.161 & 0.156 & 0.166 & 1.116 & 1.105 & 1.127 & 49.86 & 30.38 & 53.34 \\
\hline Mean & 2.55 & 2.49 & 2.60 & 0.166 & 0.158 & 0.174 & 1.097 & 1.087 & 1.108 & 46.66 & 28.73 & 50.58 \\
\hline \multicolumn{13}{|c|}{ Foliar spraying } \\
\hline K1(150ppmK) & 2.24 & 2.21 & 2.27 & 0.173 & 0.171 & 0.175 & 1.209 & 1.137 & 1.280 & 59.28 & 32.09 & 62.46 \\
\hline K2(300ppmK) & 2.41 & 2.36 & 2.46 & 0.168 & 0.166 & 0.169 & 1.399 & 1.338 & 1.460 & 63.35 & 34.86 & 66.85 \\
\hline Mean & 2.32 & 2.28 & 2.36 & 0.171 & 0.168 & 0.172 & 1.304 & 1.237 & 1.370 & 61.32 & 33.48 & 64.66 \\
\hline L.S.D. at 5\% & 0.12 & 0.13 & 0.12 & 0.105 & 0.104 & 0.107 & 0.004 & 0.005 & 0.006 & 1.088 & 1.123 & 1.112 \\
\hline
\end{tabular}

Effect of $\mathrm{K}$ rates as soil and foliar application on fruit physical properties:

Data in Tables( $2 \mathrm{a}$ and $2 \mathrm{~b}$ ) show that, increasing the applied rates of $\mathrm{K}$ increased fruit weight, fruit volume, fruit diameter, fruit length, peel weight and fruit juice $\%$. Concerning, peel thickness no trend was detected in the three seasons. Generally, the highest concentration of $\mathrm{K}$ rate was more effective and gave the highest values in regard with all the investigated physical properties.

In general, the increment was significant in all seasons. The increasing in fruit physical properties could be attributed to the applied $\mathrm{K}$ especially at the high rate. On the other hand, spraying addition was more effective in increasing all fruit physical characters and had the higher values than soil addition. Similar results were reported by many investigators such as Darwish and Ahmed (1992) on Balady orange, Hassan (1993) on Valencia orange, Salama et al; (1994) on Washington navel orange and Zeerban et al; (1994) on Balady and Succarie orange varieties .

Effect of $\mathrm{K}$ rates as soil and foliar application on fruit chemical properties:

Fayoum J. Agric. Res. \& Dev., Vol.25, No.2, July, 2011 
Regarding chemical properties, it is clear from the results obtained in Tables (3a\&3b) that increasing $\mathrm{K}$ rate, enhanced the fruit chemical properties of Balady mandarin, this increase was significant in the all seasons and could be attributed to the positive effect of increasing $\mathrm{K}$ rate in all studied traits except total acidity, which was significantly decreased by applied $\mathrm{K}$ in both methods, i.e, soil addition and foliar spraying especially at the high concentrations. In general, all studied of chemical properties of balady mandarin trees fruits except total acidity in all seasons were noticeably increased by the use of different $\mathrm{K}$ rates and the highest concentration being the most effective treatment. These finding are paralleled with those observed by Darwish and Ahmed (1992) on Balady orange, Hassan (1993) on Valencia orange, Rabeh et al; (1993) on Balady mandarin, Salama et al; (1994) on Washington navel orange and Zeerban et al; (1994) on Balady and Succarie orange varieties.

Finally, it could be decided that, foliar application had been of great importance in increasing yield and improving fruit quality of Balady mandarin.

Table (2a). Effect of $\mathrm{K}$ rates as soil and foliar application on some fruit physical properties of Balady mandarin trees.

\begin{tabular}{|c|c|c|c|c|c|c|c|c|c|c|c|c|}
\hline \multirow{2}{*}{\begin{tabular}{|l}
$\begin{array}{l}\text { Fruit physical } \\
\text { properties }\end{array}$ \\
Treatments
\end{tabular}} & \multicolumn{3}{|c|}{$\begin{array}{c}\text { Fruit weight } \\
\text { (gms) }\end{array}$} & \multicolumn{3}{|c|}{$\begin{array}{c}\text { Fruit volume } \\
\left(\mathrm{cm}^{3}\right)\end{array}$} & \multicolumn{3}{|c|}{$\begin{array}{c}\text { Fruit diameter } \\
(\mathrm{cms})\end{array}$} & \multicolumn{3}{|c|}{$\begin{array}{c}\text { Fruit length } \\
\text { (cms) }\end{array}$} \\
\hline & 2007 & 2008 & 2009 & 2007 & 2008 & 2009 & 2007 & 2008 & 2009 & 2007 & 2008 & 2009 \\
\hline K0(control) & 103.04 & 104.05 & 103.55 & 90.67 & 99.73 & 95.20 & 5.78 & 5.81 & 5.79 & 4.92 & 4.95 & 4.94 \\
\hline \multicolumn{13}{|c|}{ Soil addition } \\
\hline K1 (200gm K) & 114.47 & 116.55 & 115.51 & 104.28 & 114.46 & 104.37 & 5.86 & 5.89 & 5.87 & 5.00 & 5.05 & 5.03 \\
\hline K2(400gmK) & 118.99 & 119.09 & 119.04 & 109.06 & 119.12 & 110.09 & 5.88 & 5.94 & 5.90 & 5.05 & 5.10 & 5.07 \\
\hline K3(800gmK) & 121.27 & 122.69 & 121.98 & 111.52 & 120.73 & 112.63 & 5.92 & 6.02 & 5.96 & 5.09 & 5.14 & 5.11 \\
\hline Mean & 115.58 & 119.44 & 118.84 & 111.38 & 118.11 & 109.03 & 5.89 & 5.95 & 5.91 & 5.05 & 5.10 & 5.07 \\
\hline \multicolumn{13}{|c|}{ Foliar spraying } \\
\hline K1(150ppmK) & 135.51 & 147.51 & 136.51 & 121.50 & 126.30 & 121.90 & 6.15 & 6.18 & 6.17 & 6.45 & 6.49 & 6.47 \\
\hline K2(300ppmK) & 141.30 & 150.51 & 144.90 & 128.70 & 135.50 & 129.10 & 6.21 & 6.24 & 6.23 & 6.63 & 6.69 & 6.66 \\
\hline Mean & 143.41 & 149.01 & 140.71 & 125.10 & 130.90 & 125.50 & 6.18 & 6.21 & 6.20 & 6.54 & 6.59 & 6.56 \\
\hline L.S.D. at 5\% & 6.27 & 7.29 & 6.43 & 8.83 & 9.33 & 8.32 & 0.54 & 0.78 & 0.66 & 0.89 & 0.99 & 0.78 \\
\hline
\end{tabular}

Table (2b). Effect of $\mathrm{K}$ rates as soil and foliar application on some fruit physical properties of Balady mandarin trees.

\begin{tabular}{|c|c|c|c|c|c|c|c|c|c|}
\hline \multirow{2}{*}{$\begin{array}{l}\begin{array}{c}\text { Fruit physical } \\
\text { properties }\end{array} \\
\text { Treatments }\end{array}$} & \multicolumn{3}{|c|}{$\begin{array}{l}\text { Peel thickness } \\
(\mathrm{cms})\end{array}$} & \multicolumn{3}{|c|}{$\begin{array}{c}\text { Peel weight } \\
(\%)\end{array}$} & \multicolumn{3}{|c|}{$\begin{array}{c}\text { Fruit juice } \\
(\%)\end{array}$} \\
\hline & 2007 & 2008 & 2009 & 2007 & 2008 & 2009 & 2007 & 2008 & 2009 \\
\hline K0(control) & 0.25 & 0.26 & 0.25 & 22.75 & 22.93 & 22.84 & 52.39 & 54.27 & 53.33 \\
\hline \multicolumn{10}{|c|}{ Soil addition } \\
\hline K1 (200gm K) & 0.27 & 0.28 & 0.27 & 22.92 & 22.99 & 22.95 & 54.47 & 56.51 & 55.49 \\
\hline K2(400gmK) & 0.28 & 0.30 & 0.29 & 23.03 & 23.79 & 23.41 & 56.52 & 58.73 & 57.13 \\
\hline K3(800gmK) & 0.26 & 0.31 & 0.28 & 23.21 & 23.48 & 23.34 & 56.87 & 59.47 & 57.67 \\
\hline Mean & 0.27 & 0.29 & 0.28 & 23.05 & 23.42 & 23.23 & 55.96 & 58.24 & 56.76 \\
\hline \multicolumn{10}{|c|}{ Foliar spraying } \\
\hline K1(150ppmK) & 0.31 & 0.33 & 0.32 & 25.95 & 27.30 & 26.63 & 60.50 & 61.46 & 60.98 \\
\hline K2(300ppmK) & 0.33 & 0.35 & 0.34 & 27.75 & 29.46 & 28.61 & 61.63 & 62.13 & 61.88 \\
\hline Mean & 0.32 & 0.34 & 0.33 & 26.85 & 28.38 & 27.62 & 61.0 .6 & 61.80 & 61.43 \\
\hline L.S.D. at $5 \%$ & 0.003 & 0.007 & 0.009 & 4.51 & 4.59 & 5.01 & 11.34 & 12.28 & 11.66 \\
\hline
\end{tabular}

Fayoum J. Agric. Res. \& Dev., Vol.25, No.2, July, 2011 
Table (3a). Effect of $\mathrm{K}$ rates as soil and foliar application on some fruit chemical properties of Balady Mandarin trees

\begin{tabular}{|l|c|c|c|c|c|c|c|c|c|}
\hline $\begin{array}{c}\text { Fruit chemical } \\
\text { properties }\end{array}$ & \multicolumn{3}{|c|}{$\begin{array}{c}\text { T.S.S. } \\
\text { (\%) }\end{array}$} & \multicolumn{3}{c|}{$\begin{array}{c}\text { Total acidity } \\
\text { (\%) }\end{array}$} & \multicolumn{3}{c|}{ (r.S./acid } \\
\hline Treatments & $\mathbf{2 0 0 7}$ & $\mathbf{2 0 0 8}$ & $\mathbf{2 0 0 9}$ & $\mathbf{2 0 0 7}$ & $\mathbf{2 0 0 8}$ & $\mathbf{2 0 0 9}$ & $\mathbf{2 0 0 7}$ & $\mathbf{2 0 0 8}$ & $\mathbf{2 0 0 9}$ \\
\hline K0(control) & 10.50 & 10.55 & 10.53 & 0.845 & 0.834 & 0.842 & 12.43 & 12.53 & 12.51 \\
\hline \multicolumn{8}{|c|}{ Soil addition } \\
\hline K1 (200gm K) & 10.78 & 10.82 & 10.80 & 0.833 & 0.871 & 0.852 & 12.94 & 12.70 & 12.68 \\
\hline K2(400gmK) & 10.88 & 10.99 & 10.94 & 0.822 & 0.846 & 0.834 & 13.24 & 12.99 & 13.12 \\
\hline K3(800gmK) & 11.11 & 11.18 & 11.15 & 0.792 & 0.828 & 0.815 & 14.03 & 13.50 & 13.68 \\
\hline Mean & 10.92 & 10.66 & 10.63 & 0.816 & 0.848 & 0.834 & 13.40 & 13.06 & 13.16 \\
\hline \multicolumn{8}{|c|}{ Foliar spraying } \\
\hline K1(150ppmK) & 12.00 & 12.45 & 12.23 & 1.119 & 1.136 & 1.128 & 10.72 & 10.77 & 10.75 \\
\hline K2(300ppmK) & 12.52 & 13.00 & 12.76 & 1.115 & 1.122 & 1.116 & 11.22 & 11.69 & 11.43 \\
\hline Mean & 12.26 & 12.73 & 12.50 & 1.117 & 1.129 & 1.122 & 10.97 & 11.23 & 11.09 \\
\hline L.S.D. at 5\% & 1.56 & 1.97 & 1.78 & 0.33 & 0.67 & 0.57 & 1.34 & 1.28 & 1.43 \\
\hline
\end{tabular}

Table (3b). Effect of $\mathrm{K}$ rates as soil and foliar application on some fruit chemical properties of Balady mandarin trees.

\begin{tabular}{|c|c|c|c|c|c|c|c|c|c|}
\hline \multirow{2}{*}{$\begin{array}{c}\begin{array}{c}\text { Fruit chemical } \\
\text { properties }\end{array} \\
\text { Treatments }\end{array}$} & \multicolumn{3}{|c|}{$\begin{array}{c}\text { Reducing sugar } \\
(\%)\end{array}$} & \multicolumn{3}{|c|}{$\begin{array}{c}\text { Total sugar } \\
(\%)\end{array}$} & \multicolumn{3}{|c|}{$\begin{array}{l}\text { Ascorbic acid }(\mathbf{m g} / \mathbf{1 0 0 m l} \\
\text { juice) }\end{array}$} \\
\hline & 2007 & 2008 & 2009 & 2007 & 2008 & 2009 & 2007 & 2008 & 2009 \\
\hline K0(control) & 2.66 & 2.73 & 2.69 & 8.91 & 9.02 & 8.97 & 38.18 & 38.50 & 38.34 \\
\hline \multicolumn{10}{|c|}{$\begin{array}{l}1 \\
\text { Soil addition }\end{array}$} \\
\hline K1 (200gm K) & 2.73 & 2.81 & 2.77 & 8.97 & 9.14 & 9.06 & 39.01 & 39.18 & 39.10 \\
\hline K2(400gmK) & 2.77 & 2.87 & 2.82 & 9.03 & 9.17 & 9.10 & 39.24 & 39.33 & 39.29 \\
\hline K3(800gmK) & 2.81 & 2.94 & 2.88 & 9.17 & 9.22 & 9.20 & 39.50 & 39.55 & 39.53 \\
\hline Mean & 2.77 & 2.87 & 2.82 & 9.06 & 9.18 & 9.12 & 39.25 & 39.35 & 39.31 \\
\hline \multicolumn{10}{|c|}{ Foliar spraying } \\
\hline K1(150ppmK) & 3.19 & 3.36 & 3.28 & 10.45 & 10.52 & 10.49 & 41.25 & 41.35 & 41.30 \\
\hline K2(300ppmK) & 3.35 & 3.56 & 2.46 & 10.53 & 10.65 & 10.59 & 41.80 & 41.89 & 41.85 \\
\hline Mean & 3.27 & 3.46 & 2.87 & 10.49 & 10.59 & 10.54 & 41.62 & 41.62 & 41.42 \\
\hline L.S.D. at $5 \%$ & 0.78 & 0.88 & 0.59 & 1.56 & 1.39 & 1.76 & 3.27 & 2.78 & 3.01 \\
\hline
\end{tabular}

\section{CONCLUSION}

From the above mentioned results of the two methods of addition, It could be concluded that, foliar application was more effective for all studied properties such as yield and fruit quality of Balady mandarin especially with the high rate (300ppm) of potassium sulphate $\left(\mathrm{K}_{2} \mathrm{O}\right)$ application.

\section{REFERENCES}

Almela, V.; and Z. Agusti(1994):Hormonal control of splitting in "Nova" mandarin fruit. J.Amer. Soc. Hort.Sci. 69(6): 969-973.

A.O.A.C.(1985): Washington, D.C.

Brown, J.D. and O.Lilliland (1946): Rapid determination of potassium and sodium in plant material and soil extracts by flame photometery. Proc. Amer. Soc. Hort. Sci; 48:341-346.

Chapman, H.D. and P.F. Pratt (1961): Methods of analysis for soils, plant and waters. Univ. of California, Div. Agric. Sci; 60.

Fayoum J. Agric. Res. \& Dev., Vol.25, No.2, July, 2011 
Darwish, O.H. and F.F. Ahmed (1992): Foliar and soilapplication of urea and their effects on growth, yield and fruit quality of Balady orange trees. Accepted for oublication in Minia, J. Agric. Res. \& Dev.

El- Kassas, Sh.E., H.M.Mahmoud and S.M. El-Shazly (1987): Effect of certain micro nutrients on the yield and fruit quality of Balady mandarin. Assiut J. Agric. Sci. 18(4): 235-253.

FAUST, M. (1989):Physiology of temperate zone fruit trees. John Wiley\& Sons. Inc. USA. 230:88-93 (C.F.Hort.Abst.47:2341.

Galal,M.A;N.F.Khalil and A.F. Soloman (1987):

Effect of Nitrogen fertilization on yield and fruit quality of Round Jaffa orange trees. Fayoum J.Agric. Res.\&Dev.,Vol.1, January.

Hassan, A.E.(1993): Studies on the effect of foliar application of chelated Manganese, Iron and Zinc on Valencia orange trees. 2- The vegetative, yield and fruit quality. Menofiya J. Agric. Res. Vol. 18, No.(1): 429-442.

Khalil, H.F;A.F. Soliman and M.A.Galal (1987):Effect of potassium fertilization on yield and fruit quality of Egyptian Blood orange. Fayoum J. Agric. Res.\& Dev. Vol.1, No.1.

Maksoud, M.A.; L.F. Haggag and K.W. Khalil (1994): The nutrititional status and yield of Washington navel orange grown in sandy soil as affected by magnesium sulphate fertilizer. Annal. Agric. Sci.; Ain Shams Univ. 39(1): 365-377.

Mengel, L.X. and E.A. Kirkby (1978): Principles of plant nutrition Inter. Potash Institute. Pp.454-455.Berne, Switzerland.

Piper, C.S. (1960): Soils and plant Analysis. Inter Sci. Publishors Inc. New York.

Pregl, E. (1945): Quantitative organic micro- analysis 4 Ed; J Churchill, London.

Rabeh, M.R.M; B.Y. El- Koumeyand A. Akasem (1993): Effect of organic fertilization and some micronutrients application of Balady mandarin trees. II-Yield and fruit quality. Zagazig J.Agric. Res.; 20(6): 1865-1878.

Salama, M.I.;S.M. Zeerban and A.A.El-Morsy (1994):Effect of foliar fertilization by Potassium salts on yield, creasing, fruit quality and leaf nutrientstatus of Washington navel orange trees under Kafr El- sheikh conditions Egypt J. Appl. Sci.; 9(4): 866- 874.

Saleh, M.M. (1991): Effect of nitrogen and potassium fertilization on learning liabit and fruit quality of Balady mandarin. Annals Agric.Sci.;Ain Shms Univ. Cairo, 36(1): 163-170.

Shishova, M. and S. Lindberg (1999): Auxin cytosol acidification in Wheat leaf protoplasts depends on external concentration of $\mathrm{Ca}^{++} \mathrm{J}$. of plant physiol. 1552, 189-196 (C.F.Crop Physiol Abst 25.703).

Smith, P.F.(1970): A comparison of nitrogen sources and rates on old light yielding Valencia orange trees in Florida. J. Amir. Hort.Soc. Hort Sci.95:15-17.

Snedecor, G.W. and W.G. Cochran, (1980): Statistical Methods. The Lowa State Univ. Press; Ames, Lowa,USA.

Summer, M.E. (1985): Diagnosis and recommendation integrated system (DRIS) as a guide to orchard fertilization Hort. Abst. Vol. 55(8):7502.

Fayoum J. Agric. Res. \& Dev., Vol.25, No.2, July, 2011 
Zeerban. S.M.; M.Salama and M.A. El- Ansary (1994): Effect of foliar application on fruit set, yield, fruit characteristics and leaf nutrient status of Balady and Succarie orange varieties in Kafr El-Sheikh Governorate Egypt. J. Appl. Sci.; 9(5): 759-771.

$$
\begin{aligned}
& \text { مقارنة تأثيرات الأضافة الأرضية و الورقية للبوتاسيوم على أثجار اليوسفى البلدى }
\end{aligned}
$$

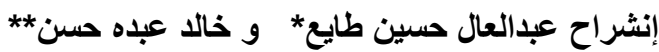

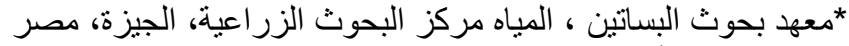

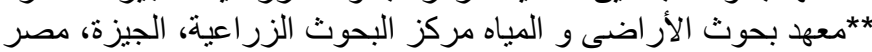

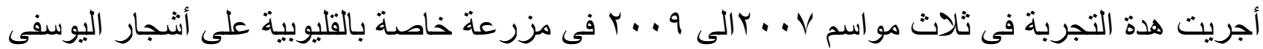

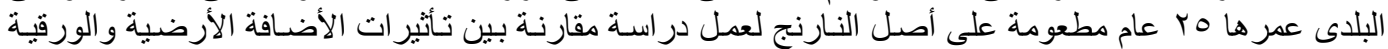

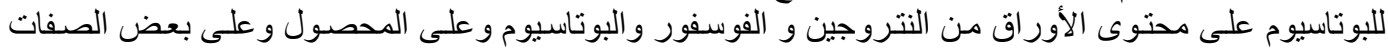

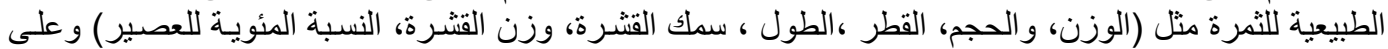

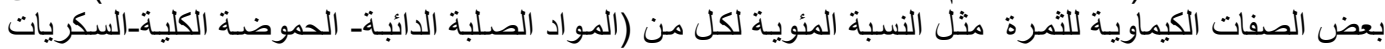

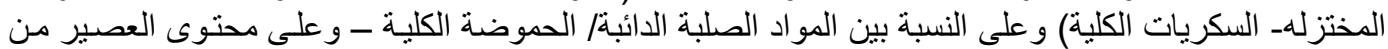

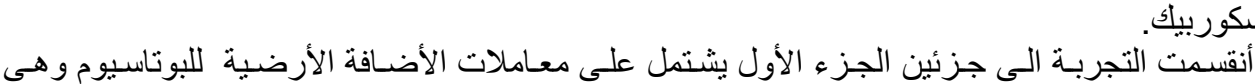

$$
\text { حمض الأسكوربيك. }
$$

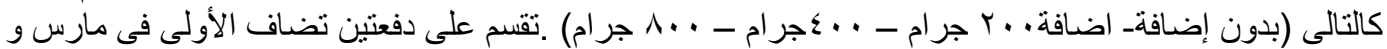

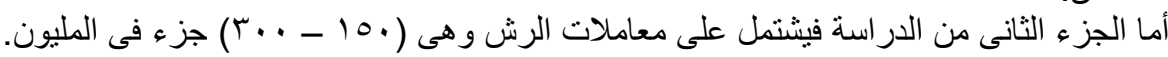

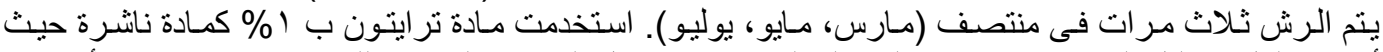

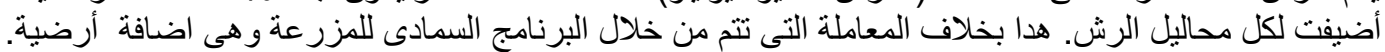

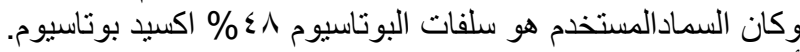

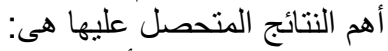

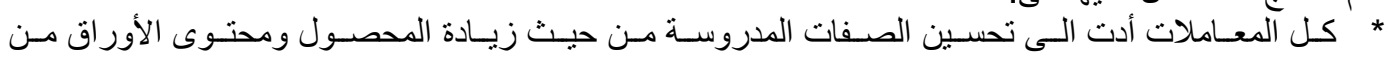

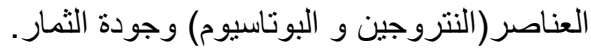

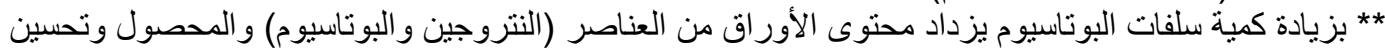

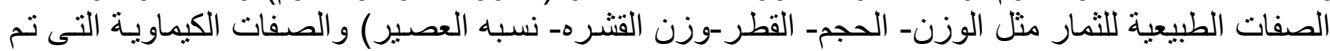

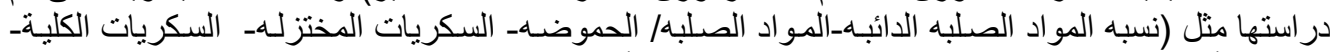

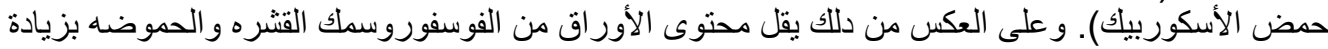
كمية البوتناسيوم المضافة.

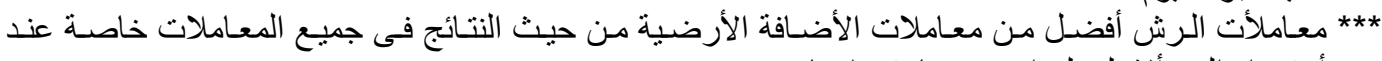
أستخدام الحد ألاعلى لهذا ينصح باستخدامها. 